Cilt / Volume 3, Sayı / Issue 3, 2020, pp. 205-218

E - ISSN: 2636-7718

URL: https://journals.gen.tr/arts

DOİ: https://doi.org/10.31566/arts.3.015

Araştırma Makalesi / Research Article

\title{
SANATÇININ MALZEMESİ OLARAK YÜRÜMEK
}

\author{
WALKING AS THE ARTIST'S MATERIAL
}

\author{
Rezzan GÜMGÜM* \\ * Sanatta Yeterlik Öğrencisi, Hacettepe Üniversitesi Güzel Sanatlar Enstitüsü \\ Resim Bölümü,TÜRKIYYE, e-mail: rgumgum@gmail.com \\ ORCID: https://orcid.org/0000-0002-1702-0927
}

\section{$\ddot{O Z Z E T}$}

Gündelik hayatın izi sürülürken sıradan bir eylem olan yürümenin filozoflarl, edebiyatçıları, din adamlarını, politikacıları, sanatçıları kentin sokaklarına ya da kırsal alanlara çekme gücü göze çarpar. Sanat ve yürüme birlikteliği tarihin farklı dönemlerinde çeşitli şekillerde ele alınmıştır; ancak yürümenin bir sanat formu haline gelişi, doğrudan eylem pratiklerini hayata geçiren Dada hareketi ile gerçekleşmiştir. Dada eylemleri ile başlayan bu karşı-sanat formu, diğer sanat hareketlerinin de katkısıyla zenginleşmiş̧tir. Bu çalışmada yürüme eylemini sanatının malzemesi yapan sanatçı pratikleri incelenecek ve sınır tanımayan yürüme eyleminin sanatta hangi stnırları dönüştürebileceği tartışılacaktır.

Anahtar Kelimeler: Gündelik Hayat, Yürüme, Dada, Sitüasyonist, Malzeme.

\section{ABSTRACT}

While the track of everyday life is being traced, walking as an ordinary action attracts philosophers, literati, clergy, politicians, and artists by drawing their attention to the streets of urban or rural areas. The unity of art and walking has been discussed in various ways and different periods, although walking has become an art form that has been actualized by the Dada movement, which directly implements the practices of action. This anti-art form began with Dada's actions has been gradually enriched through the impact of subsequent art movements. In this study, the practices of artists that used the act of walking as a material of art will be examined and the probability of changing the borders in art by the practice of walking without borders will be reviewed.

Keywords: Everyday Life, Walking, Dada, Situationist, Material. 


\section{GİRiș}

Gündelik hayatta basit olarak algılanan, sıradanlaşan, her gün tekrar ettiğimiz ve pek dikkate almadığımız bir reflekse dönüşen yürüme eylemi; içinde başı başına bir direnişi barındırır. Burada öncelikle sözü edilen direnişin kapsamını, içeriğini ve sınır(sızlık)larını açıklamak için çalışmaya öncelikli olarak "Yürüme nasıl olur?" sorusuna yanıt vererek başlamak anlamlı olacaktır.

Yürümek, ilk olarak ayakta durabilmek ve dengede kalabilmekle başlar. Sonrasında kaslar gerilir ve bacaklardan biri diğerinin önüne getirilir. Yere basan iki ayağın hareketi sayesinde ilk adım atılır. Adım atma eyleminin sürekli tekrarlanması sonucunda da bir ritim oluşur. Böylece yürüme gerçekleşir. Bu eylemin tarihsel gelişimine baktığımızda yürümenin iki ayak üzerinde durabilme ve insan anotomisinin geçirdiği evrimin tarihi ile başladığını, zamanla pratik amaçlı iki nokta arasında düşünülmeden yapılan bir ulaşım hareketine dönüştüğünü ifade edebiliriz (Solnıt, 2016:19).

İnsanlık tarihi boyunca yürümenin farklı amaçlar doğrultusunda yaşamımızı biçimlendirdiğine tanıklık etmekteyiz. Antik dönem filozoflarının yürüyüşlerinden Hac yolculuklarına ve çeşitli sivil itaatsizlik eylemlerine kadar yürüme, temel bir form olarak karşımıza çıkar. Antik dünya filozoflarının yürüyerek düşündüğü sıklıkla dile getirilir. Aydınlanma çağı filozoflarından Jean-Jacques Rousseau'nun kendi yaşam öyküsünü kaleme aldığı ve 1765-1770 yıllarını anlatan Itiraflar adlı eserinde "Yalnızca yürürken derin düşüncelere dalabiliyorum. Durduğum zaman, düşüncelerimde duruyor; zihnim yalnızca bacaklarımla birlikte hareket ediyor." cümleleri ile zihnin çalışmasını bedenin hareketiyle ilişkilendirmiş ve yürümeyi düşüncenin lokomotifi olarak ifade etmiştir (2016:33). Filozof Soren Kierkegaard ise kenti inceleme alanı olarak belirlemiş ve kent turlarını bir çeşit araştırmaya dönüştürmüştür.

Yürüme-düşünme ilişkisi kapsamında dünya edebiyatında James Joyce ve Charles Baudelaire gözümüze çarpar. James Joyce'un Ulysses adlı romanındaki roman kahramanı, zihnindeki düşünceleri ve hafızasının dügümlerini yürüyüşleri esnasında çözer. Charles Baudelaire ise Avrupa kentlerinde bilinçli bir kültürel faaliyet olarak algılanan "yürümek" kavramı çerçevesinde edebiyatta öne çıkan kent gözlemci yazarlardan biridir. Baudelaire, kenti karış karış gezen kişi anlamına gelen flâneur kavramını "Kenti en ücra köşelerine kadar arşınlar ve modern hayatın bütün görünümlerini gözlemler, ayıklar ve hafızasına kaydeder. Flâneur, kılıktan kılığa girerken onlarda erimez, aksine her defasında bireyselliğini yeniden pekiştirerek kalabalıkların peçelediği izleri sürer.” şeklinde açıklar (Baudelaire, 2013: 33).

Walter Benjamin için ise flâneur, kentin içinde başka bir gözlemciye dönüşür. Flâneur, hem çağının izini kentin sokaklarında sürer hem de modernizm ve kapitalizm eleştirisi üzerinden bu kavramı dönüştürerek sahiplenir. W.Benjamin'e göre:

Flâneur, henüz gerek büyük kentin, gerekse burjuva sınıfinın eşiğindedir. Henüz bunlardan herhangi birine yenik düşmüş değildir. Hiçbirine yerleşmiş değildir. Flâneur sı̆̆ınağını kitlede arar. Kitlenin fizyonomisine ilişkin erken çalışmalara Engels'te ve Poe'da rastlanır. Kitle, bir peçedir; bu peçenin ardından kent, bir fantazmagori niteliğiyle Flâneur'ü çağırmaktadır. Bu fantazmagori içerisinde kent, kimi zaman bir peyzaj, kimi zaman da bir iç mekân görüntüsündedir. (Benjamin, 2002: 98-99)

Flâneur, sokakta gezinen herhangi biri değildir. Tıpkı filozoflar gibi yürüyerek düşünce üretir, kenti bedeniyle deneyimler bir diğer taraftan da içeri-dışarı karşıtlığını Paris'in sokakları ve pasajlarını evi olarak görerek ortadan kaldırır. 
XIX. yüzyılda ortaya atılan flâneur kavramı XX. yüzyıl romanlarında sıklıkla karşımıza çıkar. Louis Aragon'un Paris Köylüsü romanında kent; yürüyüşler, karşılaşmalar, buluntunesnelerin keşfiyle oyunların gerçekleştiği bir mekâna dönüşür. Marcel Proust'un Kayıp Zamanlar İzinde'de ise rastlantısal gündelik yaşamın şiirsel olasılıklarını anlatan kentte gezinmeler; romanın temasını oluşturan bellek, yürüyüşler, tesadüfi karşılaşmalar ve Paris Salonları gibi unsurlarla ilişkiye geçmenin vazgeçilmez yolu olarak vurgulanır. Paris; yürümenin teorisyenleri olarak adlandırılan 1950'lerde Guy Debord, 1970'lerde Micheal de Certeau, 1990'l1 yıllarda ise Jean Chtistophe Bailly gibi pek çok kişiye ev sahipliği yapar. De Certeau, Gündelik Hayatın Keşfi'inde "Yürüyenler kenti gerçekleştirenlerdir." der. Kentin yürümek için yapıldığını, her kentin bir dil ve bir olasılıklar deposu, yürümenin ise kentin dilini konuşma ve olasılıklar arasından tercih yapma eylemi olduğunu vurgular. Ona göre dil söyleneceklere sınır koyarsa mimari de yürüyebileceğimiz yollara sınır koyar. Bailly ise “Grammaire Generative de Jambes' (bacakların üretken grameri) söylemiyle yürümeyi gerçek özne yapar (2016: 304-306).

\section{SANAT VE YÜRÜME}

Gündelik hayat pratiği olan yürümenin görsel sanatlara dâhil edilmesi, yerleşik sanatın reddini savunan Dada hareketinin sanat-hayat birlikteliğini savunması sonucu gerçekleşir. Elbette Dada'dan önceki sanatçılar imge üretmek adına yürüyüş̧ler yapmıştır, ancak istedikleri görüntüyü yakalayınca o anı imgeleştirerek dondurmuşlardır. Sanat tarihinde gündelik hayatı konu edinen birçok eserde yürüyen insanlar göze çarpar. Ancak yürüme eyleminin sanatta bir karşı form olarak ortaya çıkışı, I. Dünya Savaşı'nın dehşeti karşısında Dada hareketinin sanatın rolünü sorgulamasıyla ve sanatın varlığı/yöntemi üzerine yürüttüğü çeşitli tartışmalarla birlikte başlar. Dada, sanatı toplumu değiştiren bir eyleme dönüştürerek sanat-izleyici arasındaki hiyerarşik yapının da yeniden belirlenmesini sağlar.

Dada, sıradan nesneyi sanat yapıtı olarak sunar; farklı malzemeleri sanata dâhil eder ve yerleşik estetik anlayışı reddeder. Sanatı galeri ve müzelerden kurtararak, kentin içine sanatı taşımış doğrudan eylem pratikleriyle sanatta temsilden eyleme dönüşen bir akış başlatmıştır. Bu bağlamda Dada, sanattaki bu radikal tavrından sonra aracısız doğrudan eylem odaklı sanat hareketlerine de yön verecek ve sanatı eylem estetiğine dönüştürecektir.

Avangard hareketlere göre özgürleşmeyi sağlamanın yolu, toplumu dönüştürmekle mümkündür. Dolayısıyla avangardı savunanlar, insanlığın kapitalist modernite tarafindan hem kendine hem de doğasına yabancılaştırılmasına karşı çıkmaktadır. Yürümek bu karşı çıkışın ve dönüşümün gerçekleşmesi için yapılan eylemlerden/pratiklerden biridir. Bu pratik, zamanla Dada, Sürrealist, Fluxus hareketlerinin sanat dillerinden birine dönüşmüş ve Sitüasyonist Enternasyonel hareket ile farklı ilişkiler kurarak zenginleşmiştir.

Avangard hareketlerden biri olan Sitüasyonist Enternasyonel, Hayalci Bauhaus ve Letrist Enternasyonel'in birleşimiyle 1957 yılında kurulur. Sonrasında Londra Psikocoğrafya Birliği de harekete dâhil olur. CoBrA'dan katılan Asger Jorn ve Guy Debord liderliğindeki bu hareketin amacı ise "dünyayı değiştirmek" ve "sitüasyonlar" inşa etmektir (Artun,2013:278). Sitüastyonisler içinde bulundukları dönemde sıkışmışlık duygusuna rağmen toplumdaki özgürleştirici değişim arzusunu yaratıcı eylemlerle olası hale getirmeye çabalar. "Durum, psikocoğrafya ve dérive" kavramları ile hareketin kent mekânlarının algılama biçimine yeni bir dil katılmış, oyun kurmak bu hareketin vazgeçilmez bir unsuru olmuştur. Dolayısıyla burada sözü edilen kavramların anlamları üzerinde durulması ve metodlarının anlaşılmasına faydalı olacaktır.

Psikocoğrafya "bilinçli ya da bilinçsiz olarak örgütlenmiş coğrafi çevrenin, bireylerin davranışları ya da duyguları üzerindeki özgül etkilerinin işleyişini tanımlayan bir kavram olarak karşımıza çıkar (Coverley, 2011:14). Bu yöntem kentin bugünüyle geçmişi arasında bağ 
kurmasını sağlar, sokakları, mekânı ve ilişkileri yeniden üretir ve sürüklenme(dérive) sırasında yaşanan rastgele yön arayışının yeni karşılaşmaları sayesinde toplumsal bilincin dönüşümüne katkı sağlar.

Dérive (sürüklenme) sırasında kişi alışıldık hareket ve eylem niyetlerini, ilişkilerini ve boş zaman etkinliklerini bırakıp kendini sokağın cazibesine ve karşılaşmaların tesadüfüne bırakır. Bu durum onu kentle kurulabilecek yeni bir ilişkiye hazırlar, yaratıcı-oyuncu olması bakımından psikocoğrafi etkilere uyanık kılar. Bu bağlamda, psikocoğrafya'nın uygulama yöntemi olan dérive, kenti anlama biçimi olarak düşünülebilir (Artun, 2013:315).

Sitüasyonist hareketin öncüsü Guy Debord, Gösteri Toplumu adlı kitabında belirttiği üzere tecrit üzerine kurulu olan ekonomik sistemin ve tasarlanmış kentlerin aynı zamanda tecriti döngüsel olarak yeniden ürettiğini dile getirir. Otomobilden telefona kadar gösteri sisteminin seçtiği bütün eşyalar; "yalnız kalabalıklar"1n tecrit koşullarını yeniden üretmeye/güçlendirmeye hizmet eden, sistemin kullandığı örtük silahlardır. Bireyi sisteme dâhil etmenin yolu, kişilerin tecrit edilmiş bireyler olarak yeniden ele geçirilmelerini gerektirir. Sistem bu stratejilerini içeride ve dışarıda, her yerde uygulamaktadır. Fabrikalar ve kültür evleri, tatil köyleri ve toplu konutlar tecrit edilmiş bireyi evinin içine kadar izleyen bu sahte topluluğa hizmet etmek amacıyla özellikle tasarlanmıştır. Gösteri toplumunun stratejilerinin her alanda bizi esir aldığ ve insanı doğasına yabancılaştırdığı söylenebilir (Debord, 2018:21-93).

Sitüasyonist hareket kapitalist gündelik hayat eleştirisini kentin sokaklarını mesken edinen, politik eylem ile sanatsal faaliyeti birbirinden ayırmayan sanat pratikleri ve eylemler gerçekleştirerek yapar. Devrimi gerçekleştirecek özne ile direniş sanatını yaratacak öznenin aynı süreç içinde oluşacağına inanır. Eyleme ve harekete odaklanarak işler üreten sanatçılar karş1-sanat hareketleriyle sürecin rolünü güçlendirmiş olur. Sitüasyonist hareket, karş1kamusal alanlar yaratarak yaratıcı oyunlar aracılığıyla toplumsal bilinci dönüştürmeyi amaçlar.

\section{YÜRÜYEN SANATÇILAR}

Dada hareketinin başlattığı karşı-sanat pratikleri hem dönemin sanatçılarını hem de ondan sonra gelen sanat akımlarını etkilemiştir; günümüzde de etkisini sürdürmektedir. Dolayısıyla yerleşik sanat kurumlarını eleştiren ve sokakta sanat pratikleri ortaya koyan, bedeniyle kenti deneyimleyen ve keşfeden sanatçının kendisi bir performans aracına dönüşmüştür. Sanatçıların gerçeğin izini kentlerde, sokaklarda arayışı, durumlar inşa ederek ve eleştirel sanat pratikleri ortaya koyarak gerçekleşmektedir. Bu bölümde, sanatçının malzemesi olan yürüme ediminin, Dada öncülüğünde başlayan sanattaki yolculuğunda yürümeyi sanatın diline dönüştüren sanatçı pratikleri incelenecektir. 
Resim 1. Hamish Fulton “Tekrarlayan Yürüyüş/ Repetitive Walk”2018

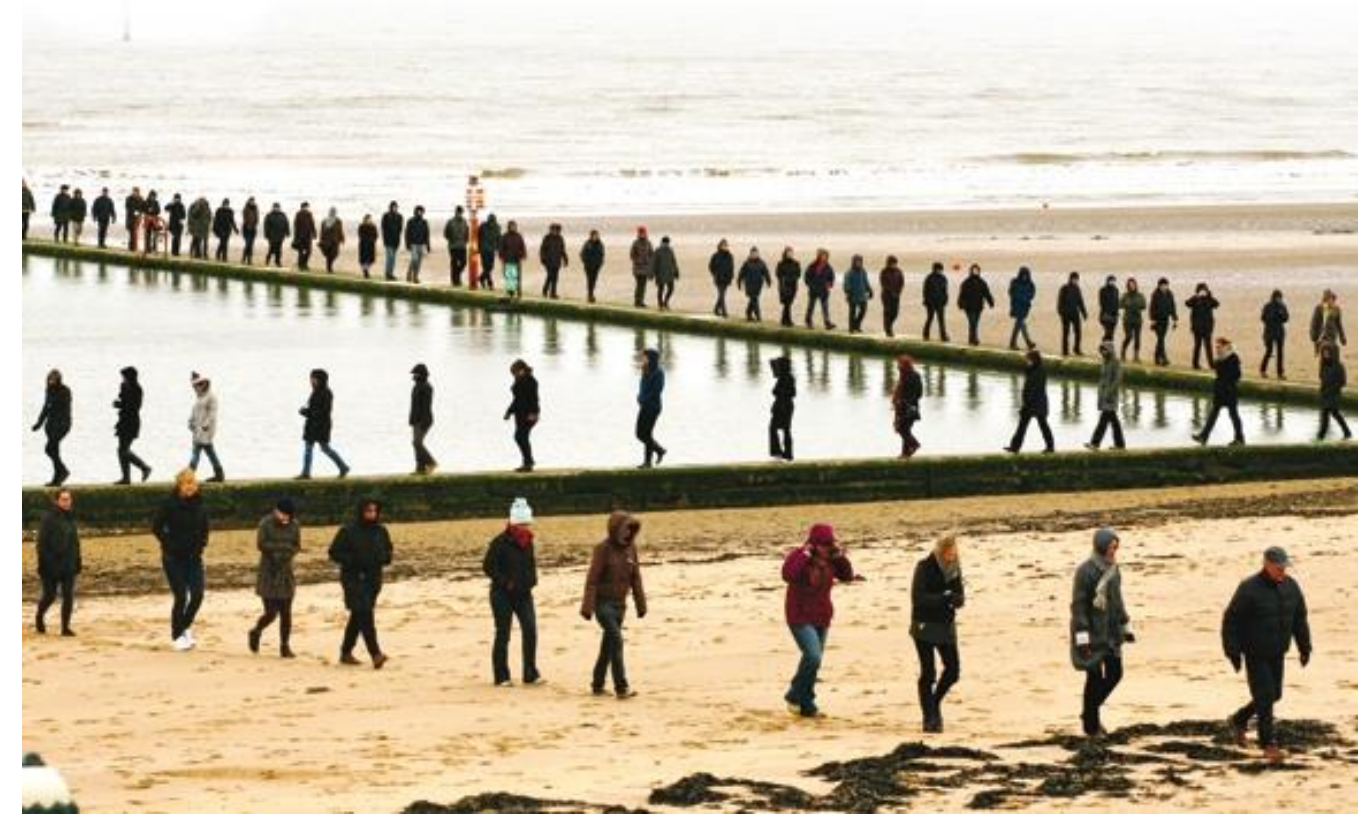

http://walkingartists.altervista.org/hamish-fulton-walk/

Sanat tarihine baktığımızda yürümeyi sanatının malzemesine dönüştürmüş olan iki isimle karşılaşırız: Aynı dönemde sanat üretimleri yapan, aynı zamanda da arkadaş olan Hamish Fulton ve Richard Long. Fulton, 1970'li yıllardan bu yana sanatta "yürümek" eylemi söz konusu olduğunda ilk akla gelen isimdir. Sanat yaşamı boyunca yalnızca yürüme deneyimlerine dayanarak işler üretmiştir. Fulton için peripatetik terimi kullanılabilir. İngilizce olan peripatetik kelimesi "uzun yürüyüşleri alışkanlık edinmiş kimse" anlamına gelir. Fulton, sanatının ilk zamanlarında hac yolculuğu güzergâhı gibi kutsal alanlara uzun yolculuklar yaparak kendi yürüme eyleminin manevi yönlerini vurgular. Yürüdüğü alanlarda yüzeylere herhangi bir iz bırakmaz. Sanatçı yürüme deneyiminin kendisini önemser. Bu eylemlerini kent alanları dışında yapar. Doğa alanlarında ya da kent içinde yapılan yürüme sırasında zihin, beden ve dünya arasında bir diyalog başlar. Yürümeye eşlik eden düşünceler birbirlerine arkadaşlık eder.

(Resim-1)'de Fulton'un son dönemde gerçekleştirdiği Repetitive Walk adlı uzun soluklu projesinden bir kare gösterilir. Fulton'un bu çalışması iki yüzden fazla kişinin sıra halinde tekrarlayan yürümelerini farklı mekânlarda devam ettiren bir projeye aittir. Katılımcıların birbiri ardına dizilişi ile oluşan çizgi, zikzaklar oluşturarak farklı görsel biçimler kazanır. Sanatçı çalışmalarını video ve fotoğraflarla kayıt altına alır. 
Resim 2. Richard Long "Yürüyerek Meydana Getirilen Çizgi /A Line Made by Walking" 1967

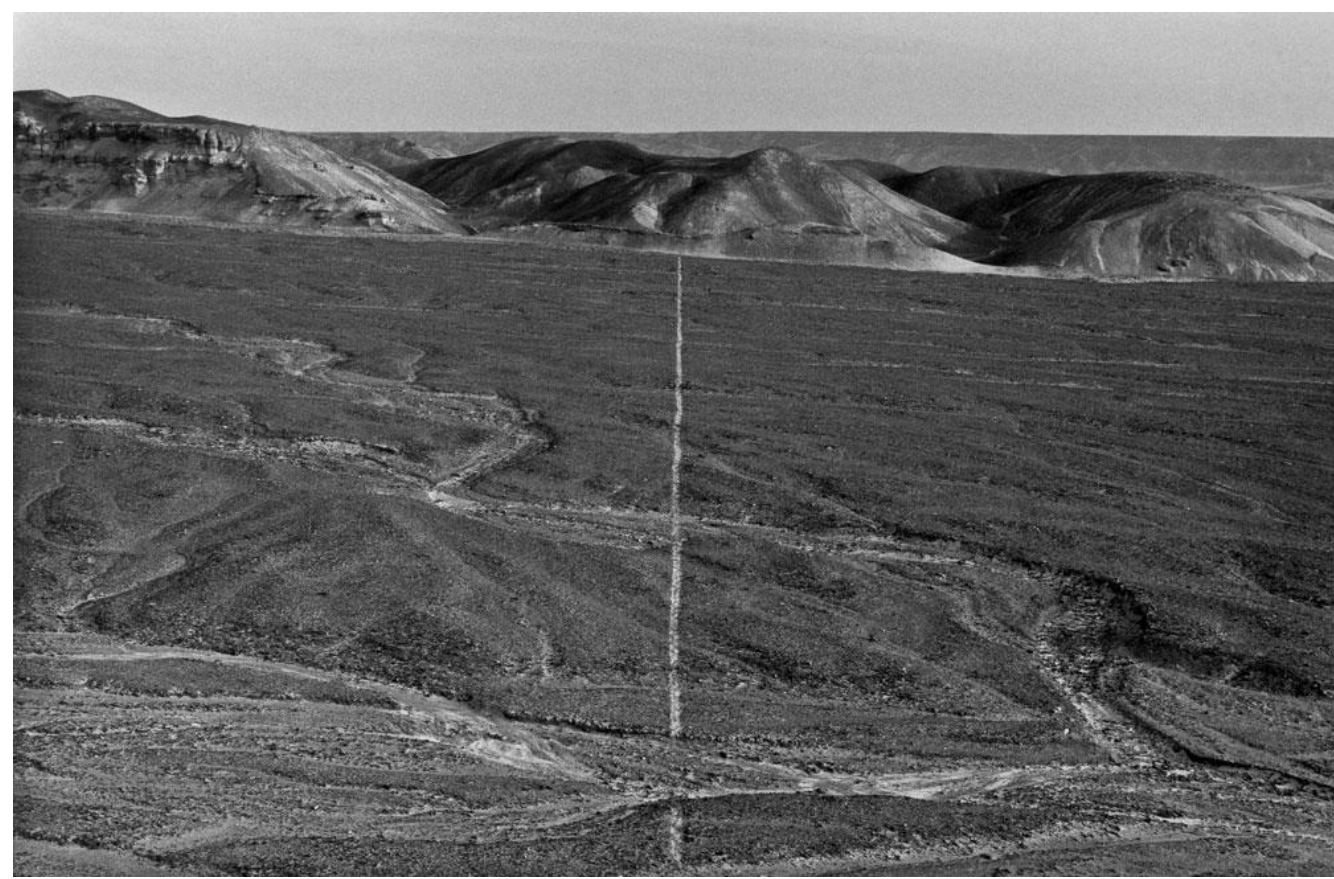

http://www.richardlong.org/sculptures.html

Sanatsal bir araç olarak yürümeyi seçmiş olan Long, çalışmalarını galeri mekânından dışarı taşıyarak zaman, mekân ve beden kavramlarını yeniden hatırlatmak istemektedir. Yaptığı yürüyüşler ile kendi kişisel haritalarını oluşturduğu söylenebilir. Aynı dönemde eser veren ve arkadaş olan bu iki sanatçıdan Fulton, yürümeyi bir tür deneyim olarak algılarken Richard Long ise yürümeyi dünya üzerinde iz bırakmaya yarayan bir araç olarak kullanır.

Richard Long, (Resim-2)'de fotoğrafı verilen A Line Made by Walking adlı siyah-beyaz fotoğraflanan bu işinde tarla gibi görünen bir arazinin uzağında, tepelere doğru çiğnenmiş çimlerin ortasında uzanan düz bir çizgiyi yürüyerek gerçekleştirir. Sonrasında sanatçı işini güneş 1şığının çizgiyi özellikle belirginleştirdiği bir açıdan fotoğraflamış, galeri duvarlarının dışında gerçek dünyanın genişletilmiş alanında çalışmış, yürümeyi keşfetmeyi birçok işinde kullanacağı malzemeye dönüştürmüştür. Sanatçının kendi bedenini işinin aracı haline getirdiği gözlemlenir.

$\mathrm{Bu}$ çalışma ilk yapıldığı dönemlerde beraberinde "Performans mi heykel mi?" tartışmalarını da getirmiştir. A Line Made by Walking, birilerine göre performans birilerine göre ise heykeldir. Her ne şekilde sınıflandırılırsa sınıflandırılsın sanatçı, yürüme eylemiyle oluşturduğu çizgileri ve daireleri ile arazinin geniş yüzeyi üzerinde gerçekleştirdiği sessiz ve özgür yürüyüşleri aracılığıyla görsel bir biçim oluşturmuştur.

Basit ve sıradan bir eylemin yaşanılan dünya ile bağımızı güçlendirdiğine, aynı zamanda çevreyle olan ilişkiler sayesinde dünyayı dönüştürdügüne tanıklık ederiz. Vito Acconci'nin aynı yıllarda farklı bir bakış açısı ile kentin sokaklarında gerçekleştirdiği yürüme edimi buna bir örnektir. 
Resim 3. Vito Acconci “Takip Edilen İşi /Following Piece" 1969

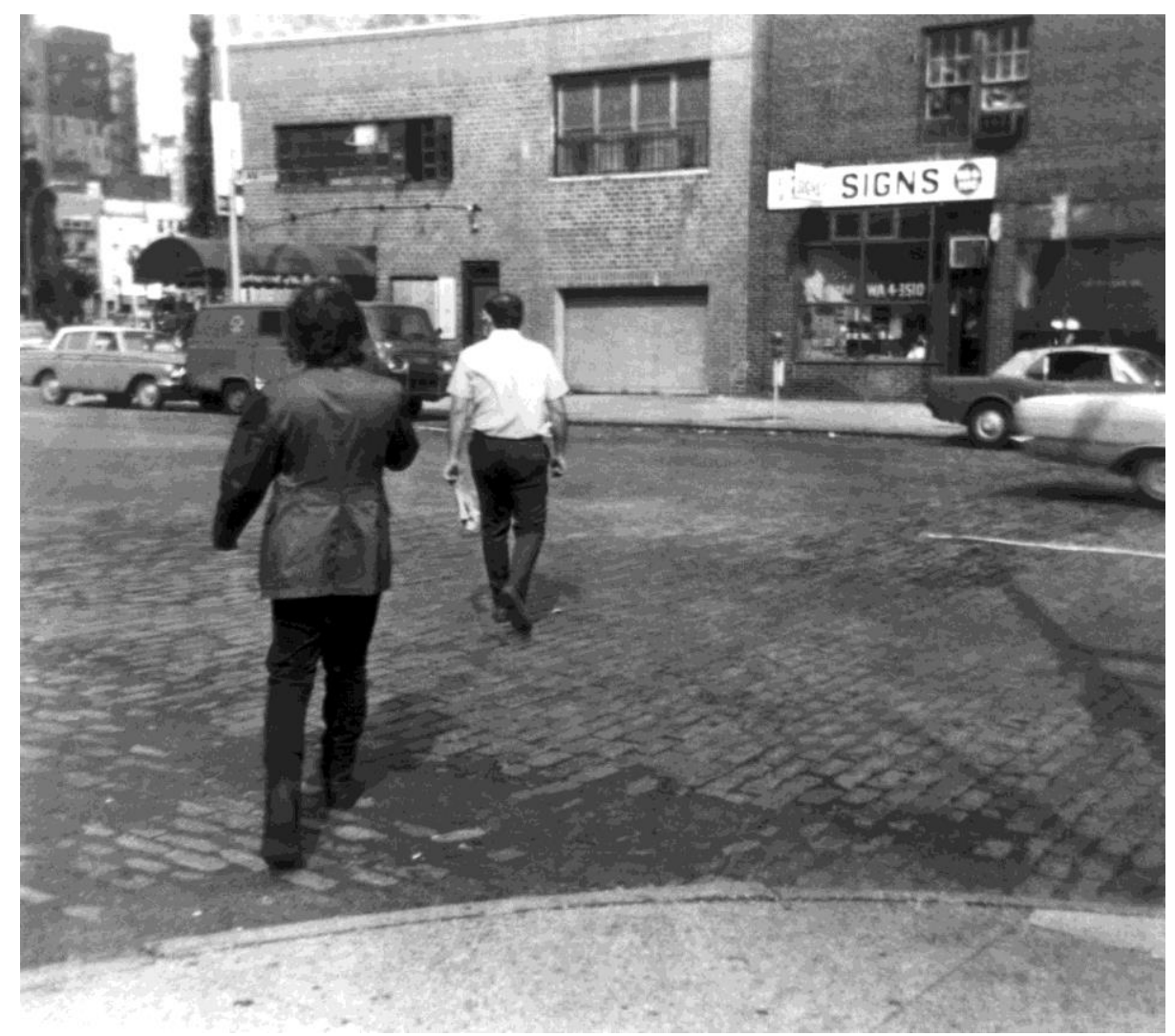

https://publicdelivery.org/vito-acconci-performances

Sanatçı Following Piece adlı işi için yirmi üç gün boyunca sokaktan rastgele seçtiği bir yabancıyı bir binaya girene kadar sokaklarda takip eder ve bu eylemini fotoğraf olarak kayıt altına alır. Performansı sırasında "Ben daha fazla 'ben' değilim. Kendimi kontrol etmiyorum. Zamanın ve mekânın dışında... Öznel ilişski... Kendimi bu planın hizmetine sundum.” gibi notlar alan sanatçı, Following Piece ile 1960'lı yılların sonlarında galeri dışına çıkarılmak istenen sanatın bir parçası olan beden, mekân, zaman gibi kavramların keşfine odaklanmış ve kamusal alanda bireyin kendi dönüşüm hikâyesini ve kentin farklı bölgelerine sürüklenmeyi deneyimlemiştir. $\mathrm{Bu}$ deneyimini çeşitli yazılar, haritalar, fotoğraflar aracılığıyla aktarmıştır (Resim-3).

Sanatçının bu çalışması, sitüasyonistlerin dérive metoduna uygun bir örnek olarak gösterilebilir. Following Piece, bir yandan bize gündelik hayatta kent içinde sınırlı hareket alanlarımızın olduğu gerçeğini hatırlatırken öte yandan sokaklarda rastgele seçilen ve bilinmeyen bir kişinin takibi sonucu hiç gidilmemiş ya da hiç girilmemiş sokakların keşfini mümkün kılan bir deneyim olur. Bireyin farklı karşılaşmalar ve ilişkiler aracılığıyla sokaklarda yeni durumları inşa edebilme potansiyelini her zaman barındıran bu tür sürüklenmelerle karşılaşması sonucunda değişmemesi mümkün değildir. "Yürümek mekândan yoksun olmaktır. Yok olmanın ve kendi aidiyetinin peşinde olmanın belirsiz operasyonudur. Kenti çoğaltan ve bir araya getiren amaçsız gezinti, kenti mekândan yoksun olmanın büyük toplumsal deneyimine dönüştürür." sözüyle kenti keşfetmenin deneyimi üzerinde durur (De Certeau, 2008: 200-201).

Sanatla gerçek deneyim arasındaki sınırı kaldıran sanatçı-teorisyen Alan Kaprow "Sıradan şeyler aracılığıyla sıradanlığın anlamını keşfedecekler. Bu şeyleri olağanüstü yapmaya çalışmayacak, sadece gerçek anlamlarını belirtecekler. Fakat işte olağanüstü olanı da bu şekilde meydana getirecekler." cümleleri ile nesne üreten bir sanatın yerine fikirler, edimler 
ve dünya arasındaki ilişkilerin araştırmasına dönüşmüş yeni bir sanat alanını dile getirir (Solnit,2016:393).

Yürüme adım adım gerçekleşir. Her adım bizi özgürlüğümüze yakınlaştırır. Coğrafyayı, kenti, kimliği, cinsiyeti belli sınırlar içine alıp hapsetmek, insanın mülkiyeti keşfiyle başlamış ve iktidar ilişkileriyle bu sınırlar belirginleşmiştir. Mona Hatoum'un (Resim -4)'te yer alan performansı tam da bu durumun imajını bize sunmaktadır.

Resim 4. Mona HAtoum “Hala Performans/Performance Still” 1985-1999

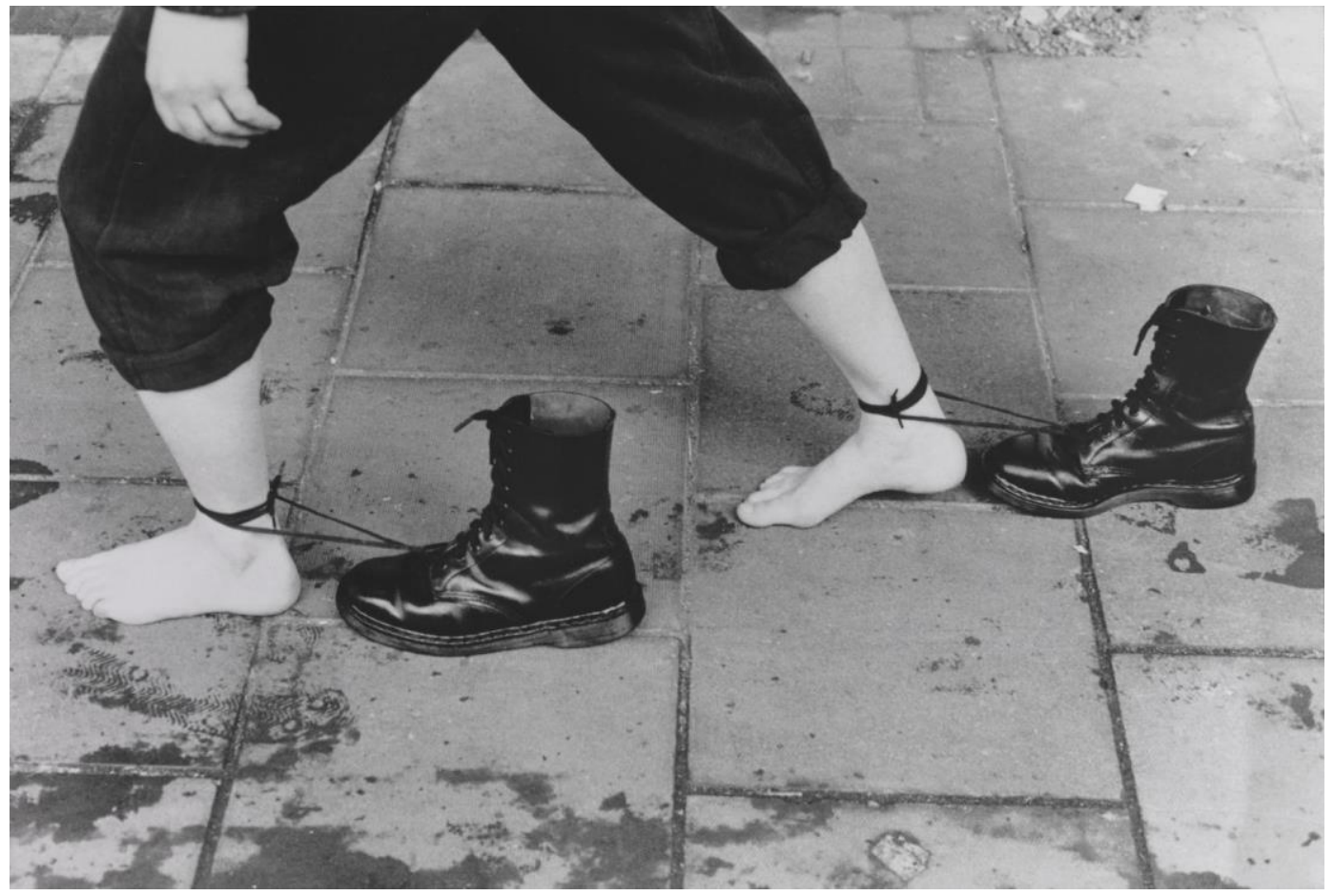

https://www.tate.org.uk/research/publications/performance-at-tate/perspectives/mona-hatoum

Mona Hatoum kendi beden deneyimleriyle işler üreten bir performans sanatçısıdır. Sanatçının Performance Still adlı işi yaklaşık bir saat boyunca Brixton sokaklarında çıplak ayakla yürümesinden oluşur. Hatoum, yürüme esnasında ayak bileklerine ayakkabı bağcıklarıyla bağlanmış Doc Marten botlarını sürükler. Performansta yer alan bu botlar genellikle polisler ya da dazlaklar tarafından giyilir. Sanatçı sokakta yürüme edimini, gündelik yaşamın sıradan bir eylemini, gündelik yaşamı modelleyen bir iktidarın tahakkümüne direnişe dönüştürür. Sanatçının performansının kaydı sırasında alınan bu imaj, yıllar sonra sanatçının belirleyici çalışmalarından biri olacaktır.

Foucault'un “İktidar her yerdedir; her şeyi kapsadığından değil, her yerden geldiğinden dolayı her yerdedir. İktidar sürekli, tekrara dayalı, cansız, kendi kendini yeniden üreten her şeyiyle, tüm bunları sabitlemeye çalışan sonuçtur" söylemi, Hatoum'un (Resim4)'te yer alan performansıyla baskı mekanizmalarını açığa çıkaran bir pratiğe dönüşür. Performance Still; eylem ve davranışlarla bedeni belli forma sokan, sınıflayan, elini ayağını bağlayan, sınırlarını belirleyen iktidarın modernist gündelik hayat pratiklerine nüfuz ederek her bağıntıda kendini üretmesine karşı bir eleştiridir (2013:69).

Yürümeyi sanatının malzemesi yapan en ihtiraslı çalışmalardan biri -performans sanatında bedenin sınırlarını en çok zorlayan sanatçılardan- Marina Abramovic ve Ulay ikilisinin gerçekleştirdiği Çin Seddi Yürüyüşü’dür. 
Resim 5. Marina Abramovic ve Ulay “Çin Seddi Yürüyüşü / Great Wall Walk”1988

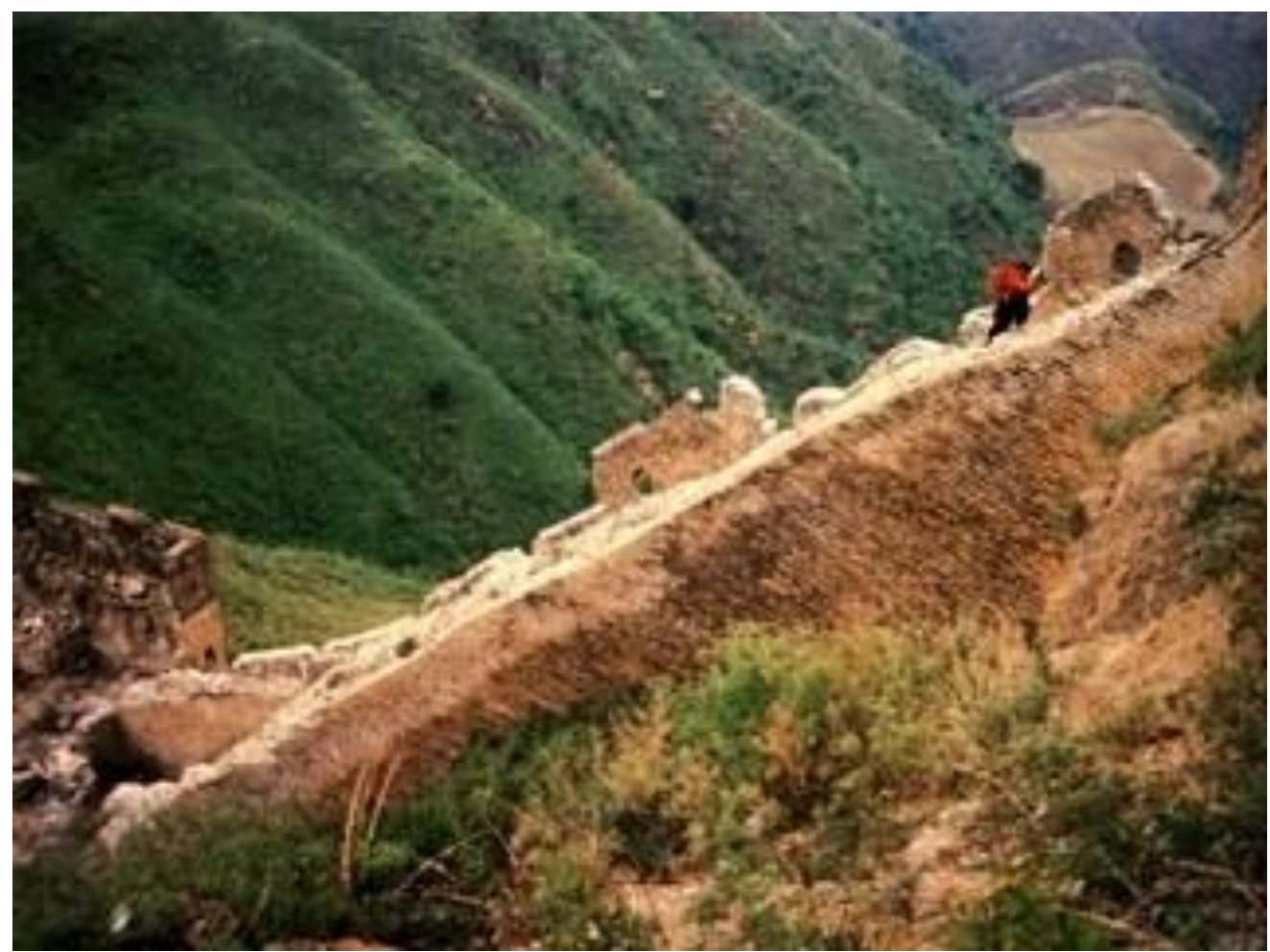

http://www.medienkunstnetz.de/works/the-lovers/

Marina Abramovic ve Ulay çok sayıda performansı birlikte gerçekleştirmiştir. Zihinsel ve bedensel sınırlarını zorlayan bu iki radikal performans sanatçısı, farklı kültürleri keşfederek sanatlarını ve kendilerini dönüştürür. Birlikte çıktıkları Tibet yolculuğu ve Aborjinlerle yaşadıkları pratikler sayesinde farklı âdetlerle karşılaşırlar. Bütün bu deneyimler ikilinin üretimlerini besler. (Resim-5)'de yer verilen Great Wall Walk yürüyüşünde iki sanatçı Çin Seddi'nin 4.000 kilometrelik duvarının iki ucundan birbirine doğru doksan gün boyunca yürürler, buluştukları noktada ise birbirlerine sarılırlar. Sonrasında yollarına ayrı olarak devam ederler. Başlangıçta bu performans on iki yıllık sanatsal ve kişisel ilişkilerinin bir kutlaması olarak planlansa da kutlama gerçekleşmez. Buluşmaları ile hem bu çalışma hem de ikilinin uzun yıllara dayanan ortaklığı sona erer.

Bedenleriyle dünyanın engin coğrafyalarında yürümenin özünü, yürümenin basitliğini ve amacını Ulay "Doğru tempoyu; yürümenin ritmik salınımında zihinle bedenin uyum bulduğu o tempoyu bulduğumu hissedene dek..." diyerek dile getirmiştir(2016:392). Sanatçıların, doksan gün boyunca yürümeleri, müthiş bir dikkat gerektirir; aynı zamanda ikilinin eylemlerine olan inançlarını gösterir. Elbette boş alanlarda yürüme eylemini gerçekleştiren sanatçılarla gündelik hayatın içinde kent sokaklarında pratiklerini gerçekleştirenler arasında yürümeye atfedilen anlam da değişir. Psikocoğrafya, kentsel bir durum olarak ortaya çıkarken, Abramovic'le bu terimin anlamı kırsal alan yolculuklarına karşılık gelir.

Gündelik hayatta günlük yürüme eyleminden uzaklaşılmış ve kentler otomobil, metro gibi araçlarla zaptedilmiştir. Birçok ülkede kent içinde yürünecek alan bulmak zorlaşmaya başladı. Kapitalist modernist sistem hayatımızı, zamanımızı, zihnimizi, kontrol altında tutma planlarını hızla sürdürmektedir. Sanatçıların kendilerine dayatılan tüm baskı mekanizmalarıyla başa çıkabilmelerinde yürüme, bir malzeme olarak onlara hem eşlik eder hem de onları özgür k1lar. 
Resim 6: Song Dong “Bir Demlik Kaynamış Su /A Pot of Boiling Water"1995

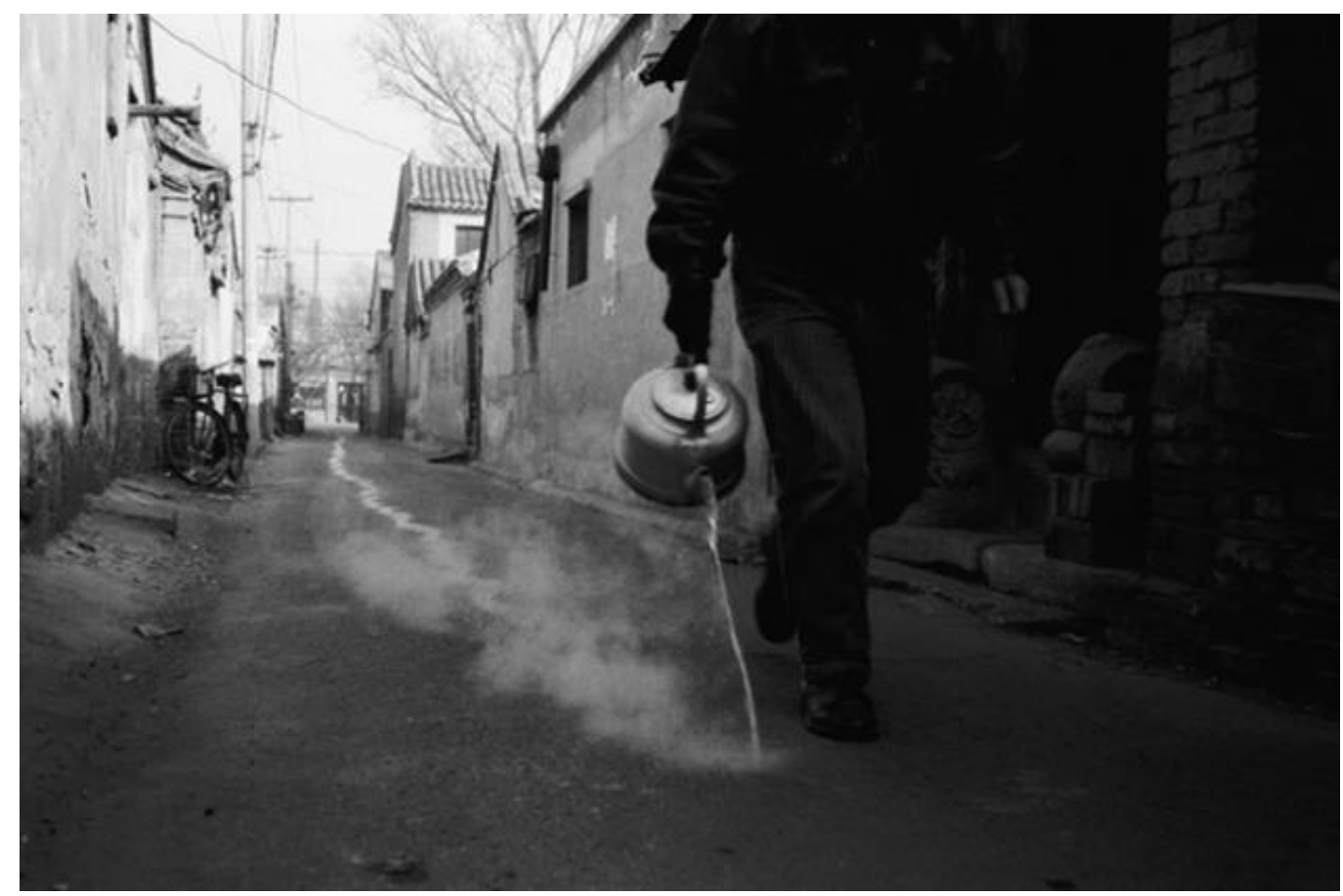

https://post.at.moma.org/content_items/1426-_breathing_

Çin çağdaş/güncel sanatının önemli temsilcilerinden biri olan Dong, Çin'in büyük politik ve sosyal değişim döneminde modern şehirleri, hayatlarının değişmesini, değişimin süreksizliğini bellek, atık, tüketim, kentsel çevre kavramları ile ilişkili olarak hayat-sanat birliğini ekseninde vurgulayan işleri ile bilinir. Kamusal alanlarda sanat yapmanın yasaklandığı bir ülkede yaşayan sanatçı yasaklarla baş edecek taktikler kullanarak sokakta eleştirel işler üretmeye devam eder. Sanatçının çalışmaları Sitüastyonist anlayışın izlerini taşır. Song Dong, "Modern Çin'de Yaşama Deneyimleri” üst başlığ 1 ile zaman, mekân ve başkalaşım kavramlarını içeren deneysel sanat yapar. Sınırlı özgürlükleri eleştirerek; sıradan, gündelik ucuz ev eşyaları ve kendi bedenini malzeme olarak kullanarak sanatını günlük deneyimleriyle birleştirir. Kent sokakları, kişisel yaşam, fiziksel çevre ve sıradan varoluş temalı çalışmaları kişisel bir karaktere sahiptir.

A Pot of Boiling Water adlı işinde sanatçı, kış ayında içinde kaynar su olan demlikle Pekin sokaklarında yürür. Demlikten yere akıtılan sıcak su buz zeminle temasında bir sis oluşturur. Sicak suyun yerde buz ile birleşimiyle suyun soğuması sonucu yerde buzdan bir çizgi oluşur (Resim-6). Sanatçı suyu bir iz bırakma, kayıt etme aracı olarak kullanır. Sanatçı bu eyleminde hızla değişen kent yaşamlarının eleştirisini yapar.

Kent deneyimlerine önem veren ve yürüme eylemini sanatının malzemesine dönüştüren bir diğer sanatçı Francis Alys'dir. Sanatçının yürüyüşleri bir varış noktası içermez. Kent içinde ya da geniş arazilerde işinin bağlamına uygun yürümeler gerçekleştirir. (Resim6)'da yer verilen Seven Walks 'tan bir araya toplandığı Guards adlı çalışması sanatçının yedi yıl süresince Londra kent sokaklarında yürüyüşlerinin video kayıtlarının bir araya getirilmesinden oluşur. Sanatçı genellikle işlerini gerçekleştirdiği sırada alınan video kayıtlarını sergiler. Yıllar süren bu çalışmasında metropol kentin gündelik yaşamında sıradan bir ritüeli olan yürümeyle gündelik yaşamı ve alışkanlıklarını araştırır. 
Resim 7: Francis Alys “Muhafizlar/ Guards” 2005

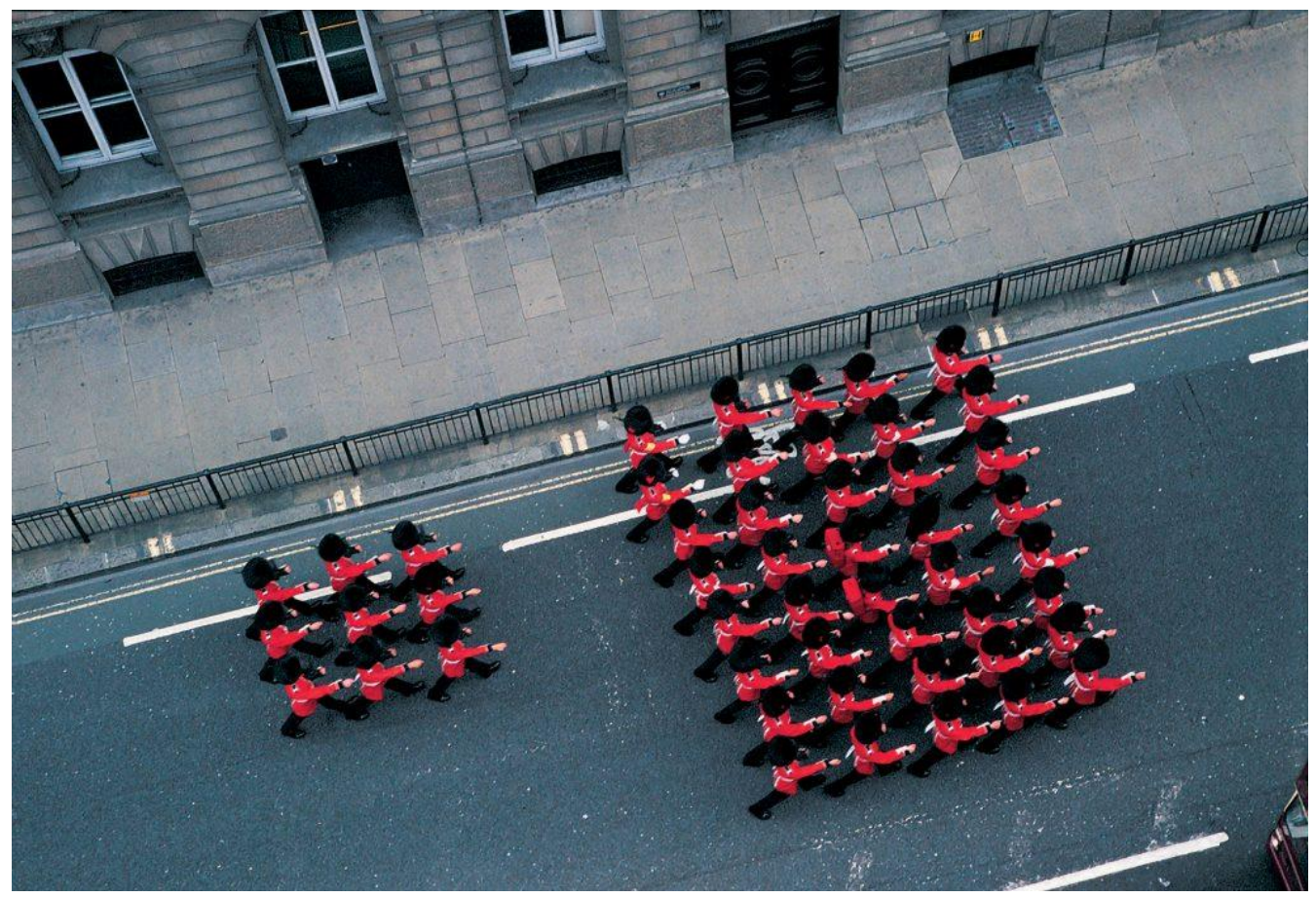

https://francisalys.com/guards/

F.Alys büyük açık-hava stüdyosu olarak adlandırdığı kenti gözlemleyerek, seslerini dinleyerek, işaretlerini ve yüzeylerini okuyarak gezinir. Şehrin farklı parçalarında gerçekleşen Seven Walks Hyde Park, Londra Şehri, Ulusal Portre Galerisi ve Regents Park'ın yakınındaki sokaklarda gerçekleşir (Resim-7).

Sanatçı, Guards (Londra Kent Muhafizları) projesini askerlerle işbirliği içinde yapar. Alys, askerlerin kentin içindeki günlük ritüellerine eşlik eder. Bir asker bir başka asker ya da bir birlikle karşılaşana kadar grupla birlikte yürür. Birlik toplanana kadar bu yürüyüş devam eder ve bütün birlik bir araya geldiği zaman en yakın köprüye kadar askerler birlikte yürür sonrasında anonim askeri kitle dağılır (Resim-7).

Cannetti, kitlenin niteliklerini "Kitlenin bir yöne gereksinimi vardır. Kitle hareket halindedir ve bir hedefe doğru hareket eder. Bütün üyeler için ortak olan yön, eşitlik duygusunu kuvvetlendirir. Tek tek üyelerin dışında, ama hepsinin paylaştığı bir hedef, böyle bir kitlenin sonu demek olan kişiye özel farklı hedeflerin üzerini örter. Yön kitlenin varoluşunun devamlılığı bakımından temel öneme sahiptir.” şeklinde açıklar. Bu bağlamda Francis Alys'in işinde yer alan askeri kitlede de bu özellikler görülmektedir (2010: 30).

Askerlerin Londra sokaklarında yürümeleri sırasında taş zemin üzerine ayaklarını sert bir şekilde vuruşlarıyla ortaya çıkan ayak sesleri bir ritim oluşturur. Birlik bir araya geldikçe duyulan ayak sesi tekleşir ve şiddeti artar. Hızlı ve ardışıklık içinde birbirine eklenen ayak sesleri kentin sokaklarında var olandan daha fazla askeri temsil eder. Askerlerin simetrik bir birlik oluşturan bloklarla birleşmesi Carl Andre'nin heykel çalışmaları ile ilişkilendirilebilir. Askerlerin parça parça bir araya gelmeleri ve yeniden ayrılmaları, sokakları mesken edinen hareketli heykelleri andırır. 
Resim 8. Pippa Bacca "Barış Gelini /Brides on Tour" 2008

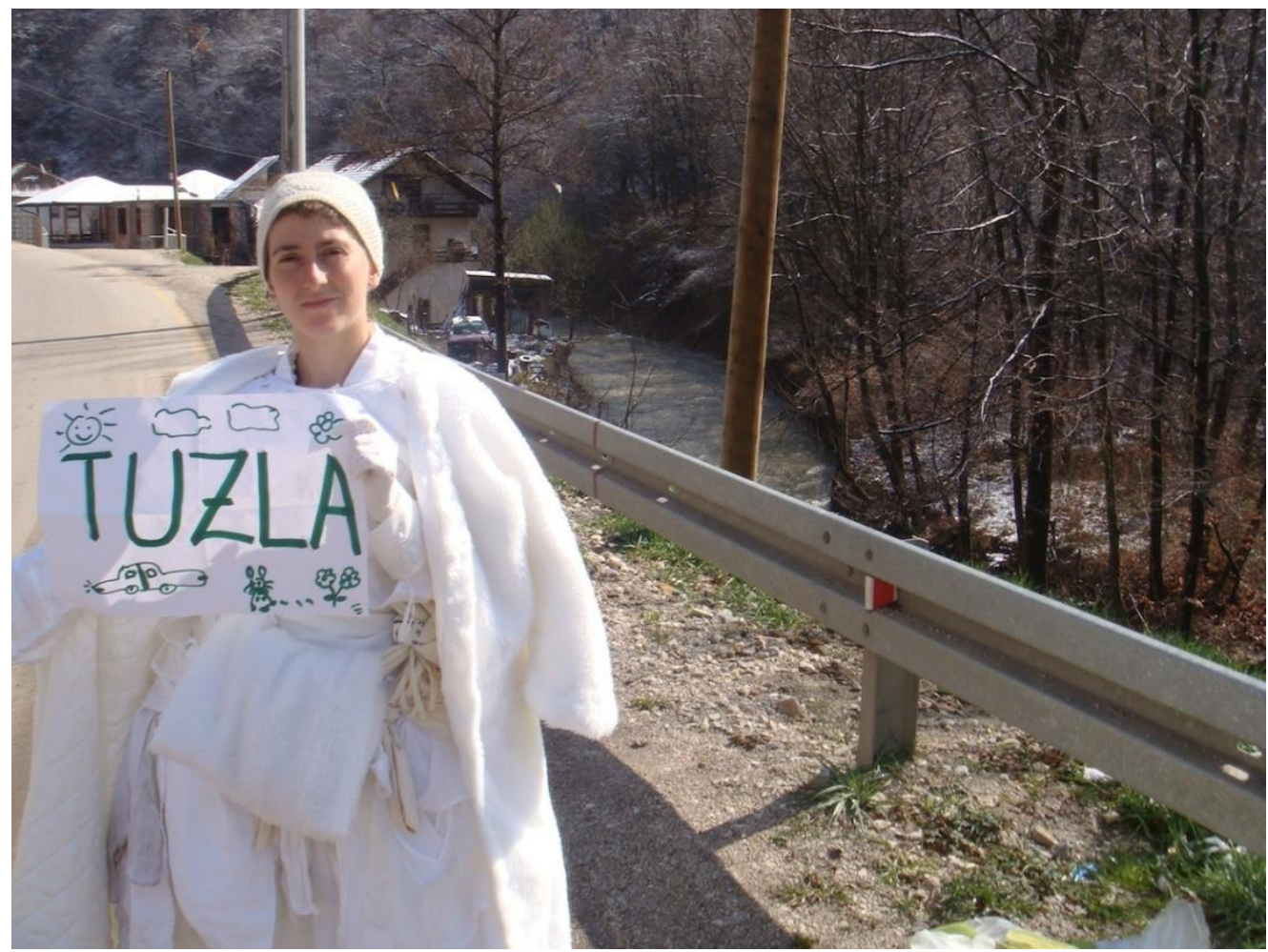

https://www.pippabacca.it/

Brides Tour adlı çalışma Feminist sanatçı Pippa Bacca (Giusepoa Pasqualino di Marinea) ve bir bașka kadın sanatçı Silvia Moro ile planlanan bir barıș projesidir. İki kadın savaşların yaşandığı bölgelere yapılmak üzere bir yolculuk planlamıştır. Bu proje kapsamında ülkelere barış ve sevgi mesajını adımlarıyla inşa etmek üzere Milano'dan başlayarak Slovenya, Hurvatistan, Bosna, Bulgaristan, Türkiye, Suriye, Lübnan, İsrail ve Filistin üzerinden devam ederek, Tel-Aviv'e kadar otostop ile ulaşmayı amaçlamışlar. 8 Mart 2008'de başlayan yolculukları, 31 Mart 2008'de Gebze'de Pippa'nın tecavüze uğraması ve sonrasında öldürülmesiyle son bulur (Resim-8).

Pipa yolculuğu kendisi için her zaman bir araç ve son olarak açıklamıştır. Ona göre yolculuk: "Bazıları için yaşamın bir yoludur bazıları için mümkün olan tek yaşam biçimi; yaşamın kendisi için bir metafordur.” (Pippa Bacca).

İki kadının başlattığı bu yürüyüşte amaçlanan, karşılaşmalar ve yeni durumların toplumsal dönüşüme katkıda bulunmasıdır. Şiddetin hâkim olduğu bölgelere, barışın ve güvenin temsili olan beyaz gelinlikleri ile farklı ülke topraklarının sınırlarını aşarak yürüyen sanatçılar bir direniş başlatmıştır. Pippa kadınlık sembolleri olan beyaz gelinliği ve topuklu ayakkabıları ile cesaret ve güç gerektiren yürüme eylemiyle barışı ve güvenin inşasını bir kadın sanatçı olarak yeniden kurabilme düşünü kurmuştur.

Bir kadın sanatçı elinde kamerasıyla başka coğrafyalara yalnız yürüyebilir mi? Yürüyüşe çıkmanın, dünyaya adım atmanın bir takım şartları vardır:

"İnsanın boş zamanı, gidecek bir yeri ve hastalık ya da toplumsal kısıtlamalarla engellenmemiş bir bedeni olması gerekir. Kamusal alan, kadınlar için çoğu zaman güvenli olmamıştır veya onları iyi karşılamamıştır. Yasal düzenlemeler, adetler, cinsel taciz, tecavüz kadınların istedikleri vakit dilekleri yerde yürüme haklarını sınırlamıştır. Sokağa çıkan kadın için sokak kadını, sürtük, kaldırım yosması ya da umumi kadın terimleri kullanılırken sokaktaki 
erkeklere, halk adamı, mahalle kabadayısı, sokakların efendisi gibi terimler atfedilir. Kadının yolculuğa çıkması kadın cinselliğinin kabul gören sınırlarını aştığını ifade eder."(Solnit,2016:333-334).

Tarihte kadınların yürümeleri "bir yerden başka bir yere ulaşmak” olarak kabul edilmez. Kadınlar sokağa çıkmışsa görülmek/seyredilmek için çıkmışlardır. Yaratılan eril toplum, bu söylemini sürekli olarak yeniden üreterek karşımıza geçer. Bütün erkek egemen yaklaşımlar, toplumsal hafizada yer edinen söylemleriyle günümüzde de devam etmektedir.

Feminist teorisyen Grimké'nin ifade ettiği gibi “Kadınları ve erkekleri kamusal ve özel alana yerleştirme girişimleri başarısız olacaktır. Aklın cinsiyeti yoktur... zihnin gücünün cinsiyeti yoktur... kadınların alanı ya da erkeklerin alanı hakkındaki fikirler keyfi fikirlerdir." (Donovan,2010:41) sözleriyle kadınlara uygulanan ayrımcılığın nedeni ve ayrımcılıkla mücadele etmenin gerekliliği ifade edilmektedir.

Sanat tarihinde yürüme edimini gerçekleştiren kahramanların çoğunun erkek olması çalışmanın giriş bölümündeki yürüme örneklerindeki erkek sayısına bakarak şunu söyleyebiliriz- gerçeğine karşın dört kadın sanatçı dikkatimizi çeker. Bunlardan Mona Hatoum'un performansı kent içinde, Marina Abromovic ve Ulay'ın performansı ise tüm dünyanın gözleri önünde fotoğraf ve video ekipleriyle gerçekleştirilmiştir. Hatoum ve Abromovic'ten farklı olarak Pippa Bacca ve Silvia Moro, kendi kameralarını alıp tek başlarına yolculuklarına başladılar. Yalnız seyahat etmelerinin nedeni dünyanın güvenilir bir yer olduğuna ve güveni sağlamanın güvenmekten geçtiğine olan inançlarıydı. Bu inanca karşın Pippa Bacca'nın tecavüze uğrayıp öldürülmesi ile yarım kalan performans, bize kadınlar için dünyanın birçok coğrafyasının -kırsal alan ya da kent merkezi- hala güvenli olmadığı gerçeğini bir kez daha gösterir. Kadın katliamlarının artarak devam ettiği günümüzde bu sorunun tarihsel bağlarıyla ele alınması gerekir. Bu da başka bir araştırmanın konusu olabilir.

\section{SONUÇ}

$\mathrm{Bu}$ çalışmanın amacı, yürüme eyleminin sanata dâhil edilme sürecini ve bir malzeme olarak yürümenin sanatçıların üretimlerine yaratıcı etkisini tartışmaktır. Dünyayı değiştirmek iddiası ile Dada sanatın varlığını tartışmaya açmış, dünyayı savaşsız, sömürüsüz inşa edebilmenin yeni yollarını yaratmak istemiştir. Sanat-hayat birlikteliğini savunan ve bunu gündelik hayatın içinde deneysel pratiklere dönüştüren sanat hareketleri, hem sanatta yeni bir alan açarak sanatı özgürleştirmiş hem de sanatın toplumsal bilinci dönüştürücü gücünü sokak eylemleriyle inşa edebilmenin olasılıklarını deneyimlemişlerdir.

Bugüne geldiğimizde ise dünyanın değişmeye ve iyileşmeye olan ihtiyacı giderek artmaktadır. Sanatçılar, yürüme eylemleriyle gündelik hayatı eleştirmeye ve farklı toplumsal sorunları konu edinerek üretmeye devam etmektedir. Yürümenin sınır tanımadığını göz önüne alırsak, sanatçılarında yürüme eylemini içeren işlerini üretirken onlara çizilen sınırları yaratıcı eylemleriyle ortadan kaldırmaya çalıştıklarını söyleyebiliriz.

Fiziksel bir eylem biçimi olan yürümek; bir yandan çeşitli kesimler tarafından bir metafor haline getirilirken diğer yandan keşfetmeyi ve düşünmeyi, ilerlemeyi, talepleri iletmenin bir aracına dönüşmüştür. Yürüme eylemi yaratıcı, özgürleştirici bir malzeme olarak sanatçının üretimlerini biçimlendirmeye ve sürekli hareket halinde olmayı işaret ettiği için de toplumsal dönüşümde önemli bir eylem olarak ele alınabilir. 


\section{KAYNAKLAR}

ARTUN, A. (2013). Sanat Manifestoları,Avangard Sanat ve Direniş,(U. Kılıç. Çev.) İstanbul: İletişim Yayınları.

BACCA, P. (2008). Bride on Tour. https://www.pippabacca.it/ (Erişim tarihi: 22.05.2020)

BAUDELAİRE, C. (2013). Modern Hayatın Ressamı (A. Berktay, Çev.), İstanbul: İletişim Yayınları.

BENJAMIN, W. (2002). Pasajlar. (A. Cemal, Çev.), İstanbul: YKY.

BERGER, J. (2014). Sanatla Direniş, (A. Biçen, Çev.), İstanbul: Metis Yayınları.

CANNETTI, E. (2010). Kitle ve İktidar, (G. Aygen. Çev.), İstanbul:Ayrıntı Yayınları.

COVERLEY, M. (2011). Psikocoğrafya Londra Yazıları, (S.Serezli,Çev.),İstanbul: Kalkedon Yayınları.

DE CERTEAU, M. (2008). Gündelik Hayatın Keşfi I,(L. A. Özcan,Çev.),Ankara: Dost Kitabevi.

DEBORD, G. (2018). Gösteri Toplumu, (A. Emekçi, O. Taşkent, Çev.), İstanbul: Ayrıntı Yayınları.

DONOVAN, J. (2010). Feminist Teori, (A.Bora,M.A.Gevrek,F.Sayılan,Çev.), İstanbul:İletişim Yayınları.

FAUCOULT, M. (2013). Cinselliğin Tarihi, (H.U.Tanrı̈ver, Çev.), İstanbul: Ayrıntı Yayınları. JOYCE, J. (2014). Ulysses. (N. Erkmen. Çev.), İstanbul: Yapı Kredi Yayınları.

SENNETT, R. (2014). Ten ve Taş, (T.Birkan, Çev.), İstanbul: Metis Yayınları.

SOLNIT, R. (2016). Yol Aşkı: Yürümenin Tarihi, (E. Kıvılcım.Çev.), İstanbul: Encore Yayınlar1. 